\title{
STRUCTURAL TYPES OF POLYVOCATIVES AND THEIR FUNCTIONAL FEATURES IN EPISTOLARY TEXTS
}

O. Kuvarova

Associate Professor, Doctor of Philological Sciences, Professor of General and Slavic Linguistics Department,

Oles Honchar Dnipro National University elkuvarova@gmail.com orcid.org/0000-0002-2925-3648

O. Budilova

$\mathrm{PhD}$, Associate Professor, Department of English Philology, Oles Honchar Dnipro National University sasha.budilova@gmail.com orcid.org/0000-0002-5143-1375

Introduction. Epistolary texts as a means of written interpersonal communication are characterized by thematic diversity, an ability to convey an almost unlimited message, and a certain structure canonized by the usus that has been established in the process of communication. To the main letter constituents that determine its genre linguists attribute the indication of the letter's date and location, salutation, address, farewell phrases and signature (Kuryanovich, 2001: 6; Prokhorov, 1964: 17-19; Reut, 2005: 116). The most significant structural element of the letter is the identification of an addressee, which has a form of a direct address, metatextual or indirect address. All these ways of the addressee identification, which establish contact between the parties of epistolary communication, are united by the term epistolary vocative. We prioritize this term over the conventional domestic term address due to the fact that vocative is an international term used, inter alia, in the English grammar. In The Cambridge Encyclopedia of the English Language, D. Crystal explains it as follows: "A vocative (from Latin vocare 'to call') is a name used for the person(s) to whom a sentence is addressed. It may be there to attract attention (as in Mike, phone for you), or to express a particular social relationship or personal attitude (as in Doctor, I need a tonic or Leave it alone, imbecile!)" (Crystal, 1995: 220). While the address lexeme retains its traditional meaning related in the Russian grammar to the name in the Nominative case and, possibly, to dependent word-forms, as part of the sentence or in a relatively independent position, and something that names a target object (Shvedova \& Lopatin, 1990: 496), we use the term vocative in a broader sense, which unites the meaning of various linguistic elements that name the addressee and serve as addressing or somehow indicate somebody's intention to established contact with a communication object. This may imply both the address, and its functional analogy, for instance, an address metatext (Golding, 1987: 52-53): To Pivden LTD CEO A. Volkov, or an indirect "thirdperson" address: Could Mr. Alexander repeat his question, please?

An epistolary vocative is a written message with a fixed speech formation, which helps establish contact between communicators; it accompanies written communication, directly or indirectly announces the letter's nature, its pragmatic, ethics and style. This formation may not be significantly different from the address used in oral communication, but at large, it is usually more comprehensive and a lot more diverse in terms of constructions. This peculiarity of the epistolary vocative is connected with something that W. Chafe described as a letter's disadvantage - its inability to ensure a quick addresser - addressee switch (Chafe, 1975: 29). Yet, alongside the addresser/addressee function, written speech gives a clearer idea of the typical traits of all parties of the communication.

As a rule, the author of the letter targets their addressee seeking to established contact at the beginning of the letter and most frequently does it only once. To implement a contact-establishing function, address is totally enough even if the vocative is not located in the beginning, by embedded 


\section{Ukrainian sense. 2020. ISSN 2313-4437}

into the main body. Such single-use addresses are referred to as monovocatives, regardless of their structure which may appear outrageously complicated and even full-scale or a disjunctive vocative construction, like, for instance, in the letter by a philosopher K. Leontiev (Мильии и дорогой мой батюшка по благодати и по сану, сынок по возрасту и умственному сродству ${ }^{l}$ (K. Leontiev to J. Fudel, 18.06.1890)) and other authors. The main thing here is the fact that the addressee is mentioned once, yet, in many letters by various addressers, the written vocative is noticed more than once for various reasons. For instance, I. Babel's letter to his wife says:

Получил, милый трибун, спешное письмо, очень меня обрадовавщее. Живу здесь хорошо, купаюсь и греюсь под солнием, которое тебе, озябшая моя московская душа, не часто снится. Все было бы хорошо, если бы мне не приходилось возить по всем городам глупые мои нервы, не умеющие работать и не умеющие спать. Я их обучаю этим ремеслам, но со средним успехом. Деньги переведу тебе телеграфно не позже второго июня. Думаю, что это не будет слишком поздно. Живи хорошо, человек затем и родился на божий свет.

Любящий тебя, душенька моя И. Б. ${ }^{2}$

(I. Babel to T. Kashirina, 31.05.1926).

In this case, we deal with a very interesting disjunctive linguistic element which we call a polyvocative. It is a system of two or more addresses spread over the text of the letter in a specific way.

Epistolary addresses have often been a focus of a linguistic research. N. Belunova, V. Zakharova emphasized a specific role of the initial address and even its necessity as one of the etiquette elements of the letter introduction (Belunova, 2000: 113; Zakharova, 1988: 111; Teleky \& Shynkaruk, 2007: 114). The linguists also highlighted the connection between epistolary addresses and the writer's individual style and the nature of the letter; in this respect, philologists' attention is drawn primarily to extraordinary, occasional, ironic addresses that are used as a means of a language game (Zakharova, 1988; Kyshtymova, 2008). There is a variety of epistolary addresses classifications based on their structural features (Klimova, 1970: 127-128) or functions they perform (Chernyaeva, 2008: 163-168). A. Kuryanovich noticed that in order to imitate direct communication and create an interlocutor's presence effect, the letter can be rich in intratextual addresses (Kuryanovich, 2012: 177). However, as far as we know, such addresses have not been reviewed as full-fledged system. Keeping in mind the fact that such systems (polyvocatives) are very diverse and arranged in a specific way, the relevance of our linguistic research lies in their exploration and classification, which constitutes the purpose of the study. This research seeks to describe the structural types of a polyvocative and to explore their main functions.

Methods and methodology of investigation. To achieve the aims, we utilized general scientific methods (observation, comparison, generalization, induction, deduction, analysis and synthesis) and linguistics-specific methods. In order to define the system of the letter's constructive features, to form the core of vocative units functioning in Russian letter, we utilized a descriptive method including observation, comparison, interpretation, generalization and classification. Epistolary vocative typology building, and the description of its components' vocabulary were done by means of linguistic modeling. The research leans on the published Russian letters of the XVIII$\mathrm{XX}$ centuries. The authors of these letters belonged to different social strata, including both poets and writers, and people whose professional activity was not related to written word - particularly, P. Annenkov, I. Babel. M. Bulgakov, O. Herzen, I. Gorbachevsky, V. Korolenko, M. Musorgsky, K. Paustovsky, P. Rumyantsev, O. Suvorov, P. Chaikovsky etc. Around one thousand of

\footnotetext{
${ }^{1}$ My dearest father by grace and rank, son by age and mental affinity.

${ }^{2}$ I received, dear tribune, a hasty letter, which made me very happy. I live here well, I bathe and bask in the sun, which you, my chilled Moscow soul, do not often dream about. Everything would be fine if I didn't have to carry around all the cities my stupid nerves, unable to work and unable to sleep. I teach them these crafts, but with average success. I will transfer the money to you by telegraph no later than the second of June. I guess it won't be too late. Live well, this is what a person was born into this world for.

Loving you, my darling.
} 


\section{Ukrainian sense. 2020. ISSN 2313-4437}

polyvocatives found in their letters were selected and chosen for analysis.

Results and discussion. A polyvocative is referred to a set of addresses used by the addresser not only to establish contact with their addressee, but also to verbally maintain this contact, ensure its continuation in time. In one-sided written communication (an addresseraddressee interaction), if it is impossible to observe the addressee's response, the letter author naturally anticipates for a reliable and ongoing contact with the addressee - the contact which is ensured (in the simplest way) through doubling the address or its multiple use with certain variations. This is the reason for different structural types of the polyvocative as such, as well as for the diversity of its constituents in separate vocative unite which build this or that element of a multiple written address - from an individual anthroponym or appellative to a multi-component vocative structure of any complexity.

The polyvocative unites the primary and secondary addressee nomination in epistolary text; hence, the lexical content of its components is determined by the essence and functions of these two nominations. The primary nomination seeks to identify the letter receiver (an anthroponym being the most reliable identifier) and to establish contact, to enhance which it is common to use lexemes with positive connotation; the secondary nomination seeks to maintain the established contact, that's why, it is most frequently implemented through appellatives, substantives, non-determined anthroponyms etc. Epistolary polyvocative typology is based on the following background: 1) the number of addresses as polyvocative components; 2) the place of these addresses in the letter; 3 ) the level of polivocative's lexical content equivalence; 4) the correlation between the first address and other components of the polyvocative.

Depending on the structure and place of epistolary polyvocative's components in the letter, we distinguish between its three constructive types: 1) a framed polyvocative, which consists of two addresses that create a frame and contains the letter in between; 2) a scattered polyvocative, which is composed of two and more (sometimes even more than ten) separate vocatives spread over the letter in a specific way; 3 ) a combined polyvocative, which is composed of at least three addresses, the first of which serves as a means to establish contact between communicators, while the last is used at the end of the letter and commonly accompanies the final etiquette formula.

Framed polyvocative implies two addresses, one of which opens the letter, and another one accompanies its final etiquette formula and signature and closes the letter. A typical example of such structure are O. Suvorov's letters to G. Potyomkin, which start with a vocative Светлейший Князь Милостивый Государь! ${ }^{3}$ and end with the same indication of the mentioned addressee Светлейший Князь Милостивый Государь! ${ }^{4}$, the final formula being Вашей Светлости всенижайший слуга 5 and the signature saying Александр Суворов ${ }^{6}$ (O. Suvorov to G. Potyomkin, 24.08.1777). This vocative may come in different variant; to be more specific, in Suvorov's letters to O. Ilovaysky they are as follows: the first vocative is Милостивый Государь мой Алексей Иванович! ${ }^{7}$, the second one does not contain a name and a patronymic: Милостивый Государь мой! ${ }^{8}$ (O. Suvorov to O. Ilovaysky, 18.07.1783). I. Babel's letter to his wife starts with the address Tamy (Tatu), and the second vocative accompanies the final etiquette formula: Целую тебя, моя душа, прошло всего два дня, и вот ты уже кажешься мне чудной и доброй9 (I. Babel to T. Kashirina, 27.03.1926). As a rule, this type of polyvocative is objectively motivated by the ethic norms of written communication, which are not supposed to be violated for no reason.

Depending on the correlation between the primary and the secondary addressee nomination in its component, the framed polyvocative can be doubling (the second address repeats the first one: мильий брат ... мильй брат (dear brother ... dear brother)), reduced (certain components of

\footnotetext{
${ }^{3}$ Most Serene Prince the Gracious Sovereign!

${ }^{4}$ Most Serene Prince the Gracious Sovereign!

${ }^{5}$ Your Lordship's most humble servant

${ }^{6}$ Alexander Suvorov

${ }^{7}$ My Gracious Sovereign Alexey Ivanovich!

${ }^{8}$ My Gracious Sovereign!

${ }^{9}$ I kiss you, my soul, only two days have passed, and now you already seem to me wonderful and kind.
} 


\section{Ukrainian sense. 2020. ISSN 2313-4437}

the first address are omitted in the second one: дорогая Аня ... Аня (dear Anya ... Anya)), expanded (something is added to the second address: мама ... милая мама (mother ... dear mother)) and modified (the components of the polivocative are totally different: дорогой Пётр Ильич ... голубчик (dear Petr Ilyich ... darling). The modified polyvocative also allows for a partial replacement of the vocative construction components. Replacement may affect both a dependent, and a core component of a word combination. Here are the examples of the modified polyvocative with a replaced determinant: мильй IП (sweet NP (hereinafter: $N$ - name, $P$ - patronymic)) ... дорогой IП (dear NP); друг мой IП ... мильй IП (my friend NP ... dear NP); многоуважаемая II ... добрейшая IП (reverend $N P$... kindest $N P$ ) etc. In the modified polyvocative, the anthroponym clearly indicating the addressee (it is essential for contact establishment) is regularly found in the first component of the framed polyvocative and is often omitted or replaced with an appellative in the second one, when the contact has been established, for instance: дорогая Люсенька ... мой друг (dear Lusenka ... my friend) (M. Bulgakov to O. Bulgakova, 30.05.1938).

The framed nature of the polyvocative is connected primarily with its functional intention: the first address, whether it is located at the beginning or (more rarely) in the middle of the letter, serves to establish contact between communicators; the second address, which accompanies the final etiquette formula and precedes the signature, serves to terminate contact. Comparing to the framed polyvocative, the scattered one has a higher potential for maintaining contact between the addresser and the addressee.

Scattered polyvocative is a type of polyvocative whereby the components are found in different places of the text but are not included into its final formula. The scattered polyvocative may comprise only two components, if the second one does not close the message, but immediately follows the first one (as we can see, for instance, in one of the letters by K. Paustovsky: Валюха, сегодня получил твоё письмо из Москвы, написанное в день приезда. Спасибо, зверь ... ${ }^{10}$ (K. Paustovsky to V. Navashina)) or is found anywhere in the middle of the letter and just maintains communicators' contact. As we can infer from the explored material, the number of the scattered polyvocative components may vary and even exceed twenty addresses per one letter. In case the number of the scattered polyvocative components rises, its quantitative traits more strongly correlate with the letter's qualitative features, its style and pragmatics. The motivation to resort to the scattered polyvocative may be either objective, when the letter size is very big and entails the need to point out to the addressee, or subjective - related to addresser's emotions, or both at the same time. The scattered polyvocative is divided into two types: homogeneous, which consists of one class of addresses, anthroponyms or appellatives, and heterogeneous, which includes both anthroponyms, and proper names, particularly, various susbtantivates.

The homogeneous scattered polyvocative with an anthroponym dominant comprises individual anthroponyms in a certain form or anthroponyms accompanied by attributes. The structure of the typical homogeneous polyvocative with an addressee's name dominant may be summarized as follows: $N \ldots N \ldots N_{\ldots}$, or $N P \ldots N P \ldots N P \ldots$ etc., possibly, with various combinations of anthroponym's forms. The main function of this type of the homogeneous polyvocative is to established contact with the addressee. A widespread modification of this polyvocative is a combination of an anthroponym and an attribute at the first address and a multiple repetition of the addressee's name further in the text. To the typical models of this polyvocative belong: многоуважсаемый IП ... IП ... IП ... IП ... (reverend $N P$... NP ... NP ... NP); дорогой I ... I $\ldots I \ldots($ dear $N \ldots N \ldots N)$; родная $I \ldots I \ldots I \ldots I \ldots$ (sweet $N \ldots N \ldots N \ldots N \ldots)$ etc. In the initial vocative construction, the anthroponym may be accompanied by several attributes, e.g.: мой дорогой, мой неоценённый, мой, мой и мой Евгений Петрович ... Евгений Петрович ... Евгений Петрович ... ${ }^{11}$ (I. Gorbachevsky to Ye. Obolensky, 22.03.1862). This sounds reasonable: at the moment of contact establishment, and addresser makes compliments to the addressee, uses emotionally-charged adjectives to highlight their positive traits and deliver own positive judgement

\footnotetext{
${ }^{10}$ Valyukha, today I received your letter from Moscow, written on the day of your arrival. Thank you, beast ...

${ }^{11}$ Dear, my invaluable, my, my and my Evgeny Petrovich ... Evgeny Petrovich ... Evgeny Petrovich ...
} 


\section{Ukrainian sense. 2020. ISSN 2313-4437}

of these traits, through which they create favorable conditions for further interaction. The next thing left to do is to maintain contact, for which purpose it is enough to call the addressee by name. the first component of the scattered polyvocative of this type bears a much higher functional load than other ones: except for a phatic, it performs an emotional and expressive function, which is determined by the semantics of typical attributes; other polyvocative components help maintain contact between communicators.

However, the homogeneous polyvocative with the anthroponym dominant quite often combines anthroponyms with attributes in various positions. Attributes may be both repeated and varied; the addressee's name may be determined not only by adjectival extenders, but also by appellatives, which creates a huge number of the most diverse combinations. Within one such nomination system, attributes or the forms of anthroponym often change, e.g.: Танюша, радость моя ... Танушка моя ... Тань-Тань ... ${ }^{12}$ (K. Paustovsky to T. Paustovska, 18.05.1953). This polyvocative is dynamic, it explicates a high emotional tension between communicators and ensures the established level of emotional contact throughout the whole process of communication.

The homogeneous scattered polyvocative with the appellative dominant contains a multiply repeated lexeme (probably, with various extenders) or different lexemes that name the addressee. The repetition of the same appellative in the letter is a quite rare phenomenon. This polyvocative more frequently combines various appellatives, in which case, as a rule, at least a part of the has dependent words, e.g.: милая моя жёнка ... ангел кротости и красоты ... мой друг ...13 (O. Pushkin to N. Pushkina, 2.10.1835). The scattered polyvocative of this type is ultimately personalized: on one hand, this way of addressee nomination is preferred by only a couple of epistolary writers, particularly, a lot of examples can be found in epistolary texts by O. Pushkin and A. Chekhov; on the other hand, even in these authors, appellative predominates and the correspondence with a limited circle of addressees, who they have the closest relationships with. The homogeneous polyvocative with the appellative dominant performs not only a phatic and emotional function, but also an aesthetic one, as it is characterized by figurativeness, includes epithets, metaphors, occasionalism, which reflects the addresser's creative approach to language.

The heterogeneous scattered polyvocative often combines the most diverse ways of addressee nomination and implies a combination of the anthroponym, appellative and substantivized adjective as well as various vocative constructions built on their basis. The dominant of this polyvocative can be represented by the component which predominates in terms of quantity; at the same time, to convey various emotional meanings that describe the details of addresseraddressee interpersonal relationships, it is equally important to choose the appropriate appellative and to prioritize a certain form of the anthroponym. The nature of the lexical dominant is determined by the addresser's attitude toward the addressee and usus accepted in their communication; it is one of the means by which the letters targeting the same respondent are united into the entire epistolary discourse.

The distribution of the scattered polyvocative components over the letter follow the rules of building epistolary text; particularly, intertextual addresses can mark those conversational units that embody in the letter such speech genres as apology, gratitude, compliment, request.

Combined polyvocative has the features of both framed, and scattered polyvocatives. It serves a frame which contains several addresses that form the scattered vocative. In other words, it is the framed scattered polyvocative, which consists of three and more addresses the last of which closes the main body of the message. Generally speaking, the combined polyvocative is motivated both objectively (the letter meets the ethic norms of written communication), and subjectively (at the same time, it can be emotionally charged).

As to the structural typology of the combined polyvocative, a significant role belongs to the correlation between the final address in the letter with the previous one. Based on the type of frame closure, it is possible to distinguish between two types of the combined polyvocative: a) the one

\footnotetext{
${ }^{12}$ Tanusha, my joy... My Tanushka... Tan'-Tan'.

${ }^{13}$ My dear wife ... an angel of humility and beauty ... my friend ...
} 


\section{Ukrainian sense. 2020. ISSN 2313-4437}

with a doubling frame-closing component, i.e., a repetition at the end of the letter of the addressed that has been used earlier in the same letter - initial or non-initial; b) the one with a modification of the frame-closing component, i.e., the non-used earlier address as the final polyvocative component. The first type can be illustrated by the polyvocative found in V. Korolenko's letter to his daughter: Дорогая моя Сонюшка ... Сонюшка ... Сонюшка ... Ну, дорогая моя Сонюшка, до свидания ${ }^{14}$ (V. Korolenko to S. Korolenko, 26.12.1914). The second type can be observed in one of the letters by $\mathrm{O}$. Herzen, who calls his fiancée by name for four times and only once by name determined by the appellative; at the end of the letter, he uses the disjunctive vocative construction which indicate a special place the addressee occupies in the life of the author: Ангел мой Наташа ... Наташа ... Haташа ... Hаташа ... друг, сестра, моя поэзия, моя святая ${ }^{15}$ (O. Herzen to N. Zakhariina, 16-18.08.1837).

The combined polyvocative combines functionally significant features of the framed and scattered polyvocatives, but it has certain peculiarities. It unites big and more diverse lexical material. Comparing to other vocative formations, the combined polyvocative more completely and vividly illustrates structural and content-based potential of written address. Finally, this polyvocative gives more opportunities for implementing pragmatic intentions of the addresser who, when resorting to this element, obtains a bigger amount of effective means to express both personal relationships between the addresser and the addressee, and individual traits of each communicator.

Conclusions. To sum up, a polyvocative is a widely used element of written communication, which forms the letter's address and ensures contact between the addresser and the addressee in the distance communication setting. To the main types of epistolary polyvocatives belong framed, scattered and combined polyvocatives. The major function of the framed polyvocative is the phatic one, i.e., establishing contact between communicators through the initial address and contact termination at the end of the letter. The scattered polyvocative seeks to maintain contact throughout the whole communication process; besides, it can also perform emotional and aesthetic functions. The components of the scattered polyvocative may mark the utterances that embody in the letter various speech genres (apology, gratitude, compliment, request etc.). This way, they can divide and integrate the text. The combined polyvocative unites the structural and functional features of the framed and scattered polyvocatives. Further research perspectives are related to exploring pragmatic traits of the epistolary polyvocative at large and its separate types in letters that function in various areas of communication.

\section{REFERENCES}

Belunova, N. I. (2000). Druzheskiye pisma tvorcheskoy intelligentsii kontsa XIX - nachala $X X v$. (Zhanr $i$ tekst pisem) [Friendly letters by art intelligentsia of the late XIX-early XX cent. (Epistolary genre and fiction)]. Sankt-Peterburg: Izd-vo Sankt-Peterburgskogo universiteta [in Russian].

Goldin, V. E. (1987). Obrashcheniye: teoreticheskiye problemy [Address: theoretical points] [in Russian].

Zakharova, V. E. (1988). O funktsiyakh i strukture nachalnogo obrashcheniya v chastnykh pismakh A. P. Chekhova [Concerning the functions and structure of the initial address in private correspondence by A. P. Chekhov]. Yazykovoye masterstvo A. P. Chekhova - A.P. Chekhov's language mastery (pp. 110-115). Rostov-na-Donu: Izd-vo Rostovskogo universiteta [in Russian].

Klimova, N. V. (1970). Struktura i stilisticheskiye funktsii obrashcheniy v pismakh I. S. Turgeneva [The structure and stylistic functions of addresses in correspondence by I.S. Turgenev]. Issledovaniya po russkomu yazyku - Research into Russian Language, 127-133 [in Russian].

Kuryanovich, A.V. (2001). Kommunikativnyye aspekty slova v epistolyarnom diskurse M. I. Tsvetayevoy [Communicative aspects of a word in M. I. Tsvetayeva's epistolary discourse]. Candidate's thesis. Tomsk [in Russian].

\footnotetext{
${ }^{14}$ My dear Sonya ... Sonya ... Sonya ... Well, my dear Sonya, goodbye.

${ }^{15}$ My angel Natasha ... Natasha ... Natasha ... Natasha ... friend, sister, my poetry, my saint.
} 


\section{Ukrainian sense. 2020. ISSN 2313-4437}

Kuryanovich, A.V. (2012). O kommunikativno-pragmaticheskoy suschnosti epistolyarnogo dialogizma (na materiale pisem V. S. Vyisotskogo) [About communicative and pragmatic epistolary essence dialogism (on the basis of letters by V. S. Vysotsky)]. Vestnik Tomskogo gosudarstvennogo pedagogicheskogo universiteta - Tomsk state pedagogical university bulletin, 10 (125), 174-179 [in Russian].

Kyshtymova, T. V. (2008). Onomasticheskaya igra v pismakh A. P. Chekhova k bratu (na primere obrashcheniy i samoprezentatsiy) [Onomastic game in A.P. Chekhov's letters to his brother [based on addresses and self-presentations)]. Izvestiya Uralskogo federalnogo universiteta. Seriya 2. Gumanitarnyie nauki - Izvestia. Ural Federal University Journal. Series 2. Humanities and Arts, 60, 221-225 [in Russian].

Prokhorov, E. I. (1964). Izdaniye epistolyarnogo naslediya [Publishing epistolary legacy]. Printsipy izdaniya epistolyarnykh tekstov: Voprosy tekstologii - The principles of publishing epistolary fiction: the issues of text linguistics (pp. 6-72). Moscow: Nauka [in Russian].

Reut, S. N. (2005). Zhanr bytovogo pisma: lingvisticheskiy i lingvodidakticheskiy aspekty [The genre of common writing: linguistic and linguodidactic aspects]. Tekst v lingvisticheskoy teorii $i v$ metodike prepodavaniya filologicheskikh distsiplin - Text as part of linguistic theory and teaching philological disciplines (pp. 116-117). Mozyr: UO MGPU [in Russian].

Teleky, M. M., \& Shynkaruk, V. D. (2007). Sotsialni katehorii modusu v tekstakh epistoliarnoho zhanru [Social categories of mode in epistolary fiction]. Kyiv; Mykolaiv: Vyd-vo MDHU imeni Petra Mohyly [in Ukrainian].

Chafe, W. (1975). Znachenie i struktura yazyika [Meaning and the structure of language]. Moscow: Progress [in Russian].

Chernyayeva, A. B. (2008). Funktsionirovaniye obrashcheniya v druzheskom pisme tvorcheskoy intelligentsii kontsa XIX - pervoy chetverti XX veka. Candidate's thesis. SanktPeterburg [in Russian].

Shvedova, N. Yu., \& Lopatin, V. V. (Eds.). (1990). Russkaya grammatika [The Russian Grammar Book]. Moscow: Russkiy yazyk [in Russian].

Crystal, D. (1995). The Cambridge Encyclopedia of the English Language. London; NewYork; Sydney; Toronto: BCA.

\section{Анотація}

Постановка проблеми. Важливим жанроутворювальним структурним елементом епістолярного тексту $\epsilon$ позначення адресата, ще має форму прямого звертання, адресувального метатекста або непрямої адресащії. Різні способи указання адресата в листі, спрямовані на встановлення контакту між учасниками епістолярної комунікації, ми об'єднуємо терміном епістолярний вокатив. Якщо адресант у межах одного листа неодноразово звертається до свого адресата, такі звертання утворюють комплекс адресувальних номінацій, кваліфікований у нашому дослідженні як полівокатив. Зважаючи на те, що полівокативи дуже різноманітні та певним чином організовані, актуальною лінгвістичною проблемою є їх вивчення та класифікація.

Метою статті є опис структурних типів епістолярного полівокатива та вивчення у зв'язку з циими типами його основних функиій.

Методи дослідження. Із метою визначення системи конструктивних параметрів листа та формування корпусу полівокативів використано описовий метод. Побудову типології епістолярного полівокатива та опис лексичного складу його компонентів здійснено із застосуванням методу лінгвістичного моделювання.

Основні результати дослідження. Виділено три структурні типи полівокатива: рамковий, розсіяний і комбінований. Рамковий полівокатив складається із двох звертань, перше з яких звичайно починає лист, друге супроводжує заключну етикетну формулу й підпис адресанта. Рамковий полівокатив може бути дублювальним (обидва звертання однакові), редукованим (у другому звертанні опущено деякі компоненти першого), розширеним (у друге звертання додано якісь компоненти) $i$ модифікованим (компоненти 


\section{Ukrainian sense. 2020. ISSN 2313-4437}

зовсім різні). Розсіяний полівокатив складається з двох або більше звертань, розподілених в епістолярному тексті, причому останне звертання не належить до кінцівки листа. Розсіяний полівокатив буває гомогенним (складається з однотипних звертань) або гетерогенним (складається зі звертань різних типів). Комбінований полівокатив містить три й більше звертань, він поєднує ознаки рамкового й розсіяного полівокативів і сумішує їхні функиії.

Висновки і перспективи. Головною функиією рамкового полівокатива є фатична, тобто встановлення контакту між комунікантами через початкове звертання та переривання контакту наприкіниі листа. Розсіяний полівокатив орієнтований на підтримання контакту, крім того, він може виконувати емоційно-експресивну та естетичну функиії. Компоненти розсіяного полівокатива можуть маркувати висловлення різних мовленнєвих жанрів (вибачення, подяка, прохання тощя) $і$ в такий спосіб виконувати функиї членування та інтеграції тексту. Перспективи иъього дослідження пов'язані з подальшим вивченням прагматичних властивостей епістолярного полівокатива та окремих його типів у листах, щзо функціонують у різних сферах спілкування.

Ключові слова: вокатив, звертання, полівокатив, лист, епістолярний текст, адресат, адресант.

\section{Abstract}

Background. An important genre-forming structural element of epistolary text is the indication of an addressee, which can come in a direct, address, metatextual or indirect address. Various ways of the addressee indication in the letter seeking to establish contact between the parties of epistolary communication, are united by the term epistolary vocative. If the addresser multiply names their addressee within one letter, such addresses build a system of address nominations that are qualified in our research as a polyvocative. Keeping in mind the fact that such systems (polyvocatives) are very diverse and arranged in a specific way, the relevance of our linguistic research lies in their exploration and classification.

Purpose. We seek to describe the structural types of the epistolary polyvocative and explore thereupon its main functions.

Methods. A descriptive method was used to define the system of the letter's constructive features and to form the core of polyvocatives. Epistolary vocative typology building, and the description of its components' vocabulary were done by means of linguistic modeling.

Results. We have identified three structural types of the polyvocative: framed, scattered and combined. The framed polyvocative consists of two addresses, the first of which commonly opens the letter and the last one accompanies the final etiquette formula and the addresser's signature. The framed polyvocative can be doubling (both addresses are similar), reduced (the second address does not contain certain components of the first one), expanded (the second address contains extra components) and modified (the components are totally different). The scattered polyvocative contains two or more addresses spread over epistolary text, in which case the last address does not belong to the letter ending. The scattered polyvocative can be homogeneous (containing one-type addresses) or heterogeneous (containing various types of address). The combined polyvocative comprises three and more addresses; it combines the features of the framed and scattered polyvocatives and unites their functions.

Discussion. The major function of the framed polyvocative is the phatic one, i.e., establishing contact between communicators through the initial address and contact termination at the end of the letter. The scattered polyvocative seeks to maintain contact throughout the whole communication process; besides, it can also perform emotional and aesthetic functions. The components of the scattered polyvocative may mark the utterances that embody in the letter various speech genres (apology, gratitude, compliment, request etc.). This way, they can divide and integrate the text. Further research perspectives are related to exploring pragmatic traits of the epistolary polyvocative at large and its separate types in letters that function in various areas of communication.

Keywords: vocative, address, polyvocative, letter, epistolary text, addressee, addresser. 